University of Nebraska - Lincoln

DigitalCommons@University of Nebraska - Lincoln

Faculty Publications, Department of Psychology

Psychology, Department of

November 2005

\title{
An exploratory study of constructions of masculinity, sexuality and HIV/AIDS in Namibia, Southern Africa
}

Jill Brown

University of Nebraska-Lincoln, jbrown@bigred.unl.edu

James Sorrell

University of Nebraska-Lincoln

Marcela Raffaelli

University of Nebraska-Lincoln, mraffaelli1@unl.edu

Follow this and additional works at: https://digitalcommons.unl.edu/psychfacpub

Part of the Psychiatry and Psychology Commons

Brown, Jill; Sorrell, James; and Raffaelli, Marcela, "An exploratory study of constructions of masculinity, sexuality and HIV/AIDS in Namibia, Southern Africa" (2005). Faculty Publications, Department of Psychology. 54.

https://digitalcommons.unl.edu/psychfacpub/54

This Article is brought to you for free and open access by the Psychology, Department of at DigitalCommons@University of Nebraska - Lincoln. It has been accepted for inclusion in Faculty Publications, Department of Psychology by an authorized administrator of DigitalCommons@University of Nebraska - Lincoln. 
Published in Culture, Health, and Sexuality, 7:6 (November/December 2005), pp. 585-598. Copyright (C) 2005 Taylor \& Francis. Used by permission. DOI: 0.1080/13691050500250198

\title{
An exploratory study of constructions of masculinity, sexuality and HIV/AIDS in Namibia, Southern Africa
}

\author{
Jill Brown, James Sorrell, \& Marcela Raffaelli \\ University of Nebraska-Lincoln and University of Nebraska Medical Center
}

Correspondence: Jill Brown, Department of Psychology, University of Nebraska, Lincoln, NE 68588-0380, USA. Email: jbrown@bigred.unl.edu

\begin{abstract}
The goal of the current study was to explore notions of masculinity and their linkages to HIV/AIDS among Owambo men and women in Namibia, where an estimated one-fifth of 1549 year-olds have acquired HIV. Thirteen open-ended interviews and three focus groups were conducted with 50 male and female participants aged 19-50 in rural and urban Namibia. Qualitative analysis revealed six central themes: the evolving meanings of masculinity, power dynamics between men and women, women as active agents, the tension between formal and informal education and HIV transmission, alcohol and masculinity, and the blending of masculinity and explanations of HIV and AIDS. The findings suggest both direct and indirect linkages between notions of masculinity and AIDS, and highlight the need for prevention efforts that focus on providing alternative avenues for attaining culturally recognized markers of masculinity.
\end{abstract}

Résumé: L'objectif de cette étude était d'explorer les notions de masculinité et leurs liens avec le $\mathrm{VIH} /$ sida chez les hommes et les femmes Owambo de Namibie, où l'on estime que un cinquie'me des personnes de 15 à 49 ans sont infectées par le VIH. Treize entretiens ouverts et trois groupes focus ont été menés avec 50 participants de sexe masculin et féminin, a`gés de 19 à 50 ans et vivant dans des zones rurales et urbaines de la Namibie. Une analyse qualitative fait ressortir six thèmes centraux: l'évolution des significations de la masculinité, la dynamique de pouvoir entre hommes et femmes, le rôle actif des femmes en tant qu'intermédiaires, la tension entre l'éducation formelle, informelle, et la transmission du VIH, l'alcool et la masculinité, la combinaison entre la masculinité et les explications sur le VIH/ sida. Les résultats suggèrent à la fois des liens directs et indirects entre les notions de masculinitéet le sida, et soulignent les besoins en efforts de prévention concentrés sur des alternatives permettant d'acquérir des marqueurs de la masculinité culturellement reconnus.

Resumen: El objetivo de este estudio fue analizar las nociones de masculinidad y sus vínculos con VIH/sida entre los hombres y las mujeres Owambo de Namibia, donde aproximadamente una quinta parte de la población entre 15 y 49 años es seropositiva. Se llevaron a cabo trece entrevistas abiertas y tres grupos de discusión con 50 participantes masculinos y femeninos, con edades comprendidas entre 19 y 50 años de zonas rurales y urbanas de Namibia. Los análisis cualitativos sacaron a la luz seis temas centrales: los cambios de significado de masculinidad, dinámicas de poder entre hombres y mujeres, mujeres en el rol de representantes activas, la tensión entre educación formal e informal, la transmisión de VIH, el alcohol, la masculinidad, la fusión entre la masculinidad y las explicaciones acerca de VIH y sida. Los resultados indican que existen vínculos directos e indirectos entre las nociones de masculinidad y el sida y señalan que es necesaria la prevención enfocada en ofrecer vías alternativas para alcanzar marcadores culturalmente reconocidos de la masculinidad.

Keywords: Masculinity, HIV/AIDS 


\section{Introduction}

Transmission of HIV, the virus that causes AIDS, happens in the most meaningful and emotionally charged moments of life, including the shared experience of sexual relationships (Bolton 1995). The activities that lead to HIV transmission are central to who we are as men and women. Because of this, efforts to stem the spread of HIV are increasingly focused on understanding how culturally constructed notions of gender and sexuality shape and constrain individuals' behaviour as they negotiate changing social and economic realities. The importance of these efforts is perhaps most clearly evident in sub-Saharan Africa, which has been disproportionately affected by the HIV pandemic.

It is estimated that 29 million (70\%) of the 40 million individuals currently living with HIV live in sub-Saharan Africa (UNAIDS 2003). With limited treatment and a lack of effective prevention programmes in many countries, there is a need to rethink intervention approaches (Parker et al. 2000). In a review of regional considerations for HIV prevention programmes, culturally defined gender roles were identified as points of concern for Africa (Raffaelli and Pranke 1995). As is true in many parts of the world, prevention efforts have failed to reduce HIV rates in most African countries, in large part because of men's resistance to behavioural change (Schoeff 1995). In response, recent efforts have focused on education and empowerment of women (Heise and Elias 1995), leading in turn to closer examinations of men's role in the AIDS epidemic (Bujra 2002). Men have been identified as both 'the solution' and the origin of the problem - in one author's words, 'the HIV epidemic is fuelled by men' (Foreman 1999: viii). It has become important to examine the theoretical underpinnings of masculinity, its assorted meanings in the midst of the HIV crisis, and its relations to HIV and AIDS. The current research is based on the belief that better understanding of the psychological and social realities of men is an important first step to designing effective programmes. This study explores how evolving masculinities are related to HIV and AIDS in a unique setting in sub-Saharan Africa. As background for our study, we review the literature on masculine identity, masculinity in southern Africa, and the Namibian context.

\section{Masculine identity}

Masculinity has been defined as a set of role behaviours that most men are encouraged to perform. Gilmore (1990) studied masculinity cross-culturally and found it to be an achieved status which almost universally includes toughness, aggressiveness, stoicism and sexuality. Scholars now discuss masculinity as a collective gender identity, one that is fluid and socially constructed, rather than a natural attribute (Courtenay 2000). Within any society multiple masculinities exist, reflecting factors like race, class, age, religious affiliation, and geographic location (Morrell 2001). But although the pluralistic nature of masculinities has been identified, not all masculinities are equal. Instead, cultural groups construct ideal notions of masculinity. This hegemonic masculinity (Connell 1987) is the ideal that men measure themselves against, and are measured against by others.

Recognizing the multidimensional nature of masculinity, several aspects have been identified, operationalized, and measured. Relevant to sexual behaviour, men's health behaviours often demonstrate a denial of weakness, virility, the appearance of being strong, and emotional and physical control. It is often in the pursuit of power and privilege that 
men are led to harm themselves (Courtenay 2000). In addition, perceived inability to meet cultural benchmarks of normative masculinity may result in anxiety, depression and hostility (McCreary et al. 1996). Changes in the dominant masculine identity within a specific culture, and varying access to hegemony, creates heightened opportunities for role conflict and stress that are highly relevant to other areas of functioning, including sexuality, as men often express and experience masculinity through sexuality (Campbell 1997, Seal and Ehrhardt 2003).

\section{Masculinity in Southern Africa}

Morrell (2001: 338) has described the construction of masculinities in southern Africa as both 'a local and a global process'. Globalization reshapes the arena in which notions of masculinity are expressed, necessitating an in-depth examination of transformations that are occurring in particular contexts. In times of change, men demonstrate a reactive, accommodating or progressive response.

Past research in sub-Saharan Africa has revealed linkages between notions of masculinity and sexuality. For example, Price and Hawkins (2002) reported that young men in Zambia talked about sexual relationships as central to their self esteem and social status. Similarly, in a Xhosa township in South Africa, the number of girlfriends a boy has is a defining feature of what it means to be a man (Wood and Jewkes 2001). Deeply-held notions of male privilege in the domains of sexual negotiations and family decision-making have been reported among post-independent migrant workers in South Africa (Campbell and Williams 1996).

The implications of notions of masculinity for sexual behaviour change have also been explored. Campbell (1997) has reported that masculine role expectations limited intervention programme effectiveness among South African mine workers, who endorsed

(a) a heightened sexual desire driving them to seek multiple partners; (b) a lack of caution in high risk situations; (c) a need for pleasure of 'flesh on flesh sex'; and (d) the desire to father many children. Other research finds that condom use mitigates against young men's notions of masculinity in South Africa (Abdool-Karim et al. 1992). The need for men to engage in sex with multiple partners, combined with negative attitudes towards condoms and the primacy of fertility, place their sexual health at risk (MacPhail and Campbell 2001). Critical to this research is the link between the multidimensional and evolving nature of masculine identity in an African community and continuing high-risk sexual behaviour despite widely dispersed information about HIV and AIDS.

At the year 2000 International AIDS conference in Durban, South Africa, multiple presenters highlighted alcohol misuse as a behavioural risk factor for HIV transmission (e.g., Mufune et al. 2000). It has been well documented that alcohol consumption is strongly associated with failure to use condoms and higher HIV seropositivity in sub-Saharan Africa (Mbulaiteye et al. 2000, Myer et al. 2002). Men tend to drink more than women and have more alcohol-related problems (Parry et al. 2002, Wojcicki 2002). Social identities form around whether men are 'drinkers' or 'church-goers' in Zimbabwe (Pattman 2001). This literature suggests that in some contexts at least alcohol may represent a key factor to consider in understanding linkages between masculinity and HIV in sub-Saharan Africa. 


\section{The Namibian context}

Namibia is rich in diversity with 13 different ethnic groups and half of the population speaking Oshiwambo. Namibia gained its independence in 1990 after more than a century of colonial rule, first by Germany and then by South Africa. Currently, rural and urban lifestyles coexist. Mining accounts for $25 \%$ of the gross domestic product and many men migrate to work in mines, while others seek work in cities. Over two-thirds of the population continue to live traditional rural lifestyles in the rural North, where $50 \%$ of the population depends on agriculture.

HIV is endemic in Namibia, with an estimated prevalence rate of $21.3 \%$ among $15-$ 49 year-olds (UNAIDS 2003). Ongoing public health initiatives and a functional public health system are in place, resulting in high levels of awareness and knowledge about HIV and AIDS. Prevention programmes in Namibia, as elsewhere in the developing world, have followed the KABP model (knowledge-attitudes-beliefs-practises) that assumes that health related decisions are based on knowledge and attitudes (Fitzgerald et al. 1999). Nevertheless, even people with high levels of knowledge about HIV/AIDS often engage in high-risk sexual behaviours (Campbell and Williams 1996), emphasizing that information is just one determinant in the complex process of bringing about behavioural change. To date, in-depth research on masculinity, sexuality and HIV has not been conducted in Namibia. However, Mufune (2003) has reported a weakening of the link between community morals and sexual behaviour, resulting in more liberal sexual attitudes. In addition, poverty, work migrancy, and inequitable gender relations have been highlighted as critical factors in the rapid increase in HIV prevalence rates in Namibia (Mufune et al. 2000, LeBeau et al. 1999).

With little published literature available on Namibia, this qualitative study represents a first step in understanding the social and psychological factors contributing to the HIV pandemic. The overarching goal was to explore notions of masculinity and their linkages to HIV among Owambo men and women in Namibia, Southern Africa. We addressed two primary research questions. First, what are the meanings of masculinity in Owambo society? Second, what are the linkages between notions of masculinity and HIV/AIDS?

\section{Methods}

\section{Participants and procedures}

Qualitative research involving semi-structured key informant interviews $(n=13)$ and three focus groups $(n=37)$ was conducted during March of 2001. In addition, numerous informal talks and observations were made during the first author's extended stays in Namibia. Interviews and focus groups were conducted at three sites of varying urbanicity and size: Eenhana (pop. 600), Ongwediva (pop. 30,000) and Windhoek (pop. 200,000+). Through prior work on HIV prevention in Namibia, the first and second authors identified local and national leader key informants. Key informants in the north (Eenhana, Ongwediva) consisted of male and female young people (aged 19-30), health care workers, teachers, clergy, traditional headmen, and government leaders. In Windhoek, key informants included university faculty, United Nations agency representatives, and male and female young people (aged 19-30). Two single gender focus groups (12 women aged 21-49, 13 men aged 18-35) were recruited from the Eenhana community centre and local bars. A third mixed gender focus group was recruited from Ongwediva Teacher's College $(n=$ 
12 , men and women aged 23-49). Participants averaged 32.8 years of age ( $\mathrm{SD}=9.2) ; 30$ $(60 \%)$ were males and $20(40 \%)$ female; over half reported their primary residence as rural $(n=29,58 \%)$ and the rest urban $(n=21,42 \%)$.

Following procedures approved by the Institutional Review Board at the University of Nebraska Medical Center, participants gave verbal informed consent for study participation. Prior to data collection, the first and second author introduced the goals of the research and emphasized the exploratory nature of the work. Interviews and focus groups were conducted in English with an Oshiwambo interpreter present. Interviews lasted about one hour and responses were hand written by the researcher. Focus groups lasted approximately 1.5 hours and responses were audio-taped when possible. Interviews and focus groups were discussed by the researchers and translator at the end of each day looking for meaning and insight. This ongoing interpretation allowed additional exploration of relevant issues.

\section{Interview protocol}

Key informant interview and focus group protocols consisted of open-ended questions on four main topics: gender norms and masculinity, alcohol use, sexuality, and HIV/AIDS. Topics were identified from the existing literature as well as prior experience in Namibia. Sample questions included: 'What does it mean to be a man?', 'How has that changed?', 'What is the role of alcohol in your community?', 'What are the obstacles to practicing safer sex?', and 'What is men's responsibility for HIV/AIDS?'. Additional questions were asked to follow-up specific responses.

Coding and data analysis. The written and audio-taped responses were transcribed in English by the first author and analysed for themes following a qualitative approach (Creswell 2003). Transcripts were reviewed by the first author and a trained undergraduate research assistant to identify emergent themes. First, the two coders worked independently to locate segments of the transcripts that corresponded to questions about masculinity and HIV. Next, secondary theme codes were generated. Codes were compared and the researchers discussed discrepancies until a consensus was reached.

Themes described in this paper met the following requirements: (1) both men and women had discussed the theme, and (2) the theme was mentioned by more then half of all participants. This information has been compiled with the understanding that individuals will vary in the extent to which they adhere to societal norms and expectations. We encountered instances of contradictions, and negative case analysis is presented in these instances.

\section{Results}

Six major themes emerged from the analyses that are directly relevant to our central questions: 'what are the meanings of masculinity?' and 'what are the linkages between notions of masculinity and HIV/AIDS in Namibia?'

\section{'To be a man': Past and present}

There was widespread agreement among respondents about what constituted traditional and contemporary ideals of Owambo masculinity. Across focus groups and interviews, both men and women identified having more than one wife as a right and a necessity. One man said, 'It is about wealth, you may have as many wives as you can support'. Men typ- 
ically spoke about the need for children and wives, often citing that their strength depended on having more than one wife and many children. Women agreed:

If you had many wives, many children will come your way ... that is most important and that is how you became a man. I knew a man in Omusati region with 100 children. People threw him a very big party when the number 100 was born. (Woman, KI, rural)

Other indicators of traditional masculinity included what men owned. When Owambos were primarily agriculturalists, cattle were a currency by which people traded goods and services (e.g., bride price). Similarly, the size of a man's millet field was often identified as the mark of a strong man.

Being a man, in our tradition, one needs more than one wife. You are lucky if you are the first. That is for sure. Also, a big mahango (millet) field, many cattle, and many, many children. The work is not easy but with more women and children the man's fields will be cared for and he will have much food. (Woman, single-sex FGD, urban)

Informants recalled past ideals of masculinity with reverence as well as an acknowledgement that change was happening. A few respondents spoke about fathers and uncles but most described grandfathers and old head men as examples when asked what it used to mean to be a man. In contrast, a wider range of possessions is now needed to fulfil the definition of manhood. Respondents living in rural areas continued to report cattle and a large omahango field when asked what it means to be a man, but expanded the definition to encompass western ideals of status. As one rural man said, 'Being a man is having money, many girlfriends, and a car. We are behaving like other cultures like on television but not using the best of those cultures, only the worst'.

As migration moves people from their homes in the North to urban areas, men move between the urban and rural life, at times with ease, and at time with apprehension and pressure. Successful men often carry the burden of a family in the city and a large extended family in the rural North. One male informant said 'it doesn't stop. I am it. The only one to make any money. I am caring for Memekulu (grandmother), I am providing and providing'.

For urban men, current definitions of masculinity encompass an array of modern possessions. In the words of one urban woman, 'I believe the times have changed. Today you need girlfriends and property, like your own business, a car, money. These are not always easy'. The difficulty of obtaining these markers of masculinity was noted by one urban man: 'I think I will buy a Toyota, but the problem is there is no money so I just dream of it'.

\section{'The worst is to be afraid of the ladies': Girlfriends and power}

Several informants noted that in Owambo culture the road to marriage allowed men the liberty to have several sexual partners; after marriage, polygamy also permitted men to have multiple sexual partners. An important element of contemporary masculinity, which may represent a reinterpretation of these traditional practises, is the importance of having girlfriends and non-marital sexual partners:

Multiple sexual partners are part of tradition and to have just one suggests poverty, low status, and weak manhood. If I can support many women I am strong and rich. (Man, single-sex FGD, rural) 
Key informants and focus group participants agreed that men typically have girlfriends away from home. Examples included teachers who have wives in the capital and girlfriends in the community where they work. Similarly, men working in urban areas will have girlfriends in the city while maintaining a home and a wife in the village. Participants agreed that having many girlfriends represents one way of achieving high status as a man:

You need to have the ability to get girls and to have children. Perhaps you are handsome then that is a good thing. Perhaps you have money. That is also good. The worst insult is to be afraid of the ladies, they call you a woman, or HIV positive. (Woman, mixed-sex FGD, urban)

Women recognized the importance of multiple partners in defining manhood. However, some women expressed ambivalence and anger about this practise, in light of the HIV/ AIDS epidemic. One women complained:

In Eenhana the men never turn up for the AIDS meetings they are probably with their girlfriends during the AIDS meetings. Only women turn up. (Woman, KI, rural)

There was recognition among participants that traditional gender roles favoured men. Both rural and urban men generally agreed they held and were free to exercise power in sexual situations. As one man said:

Men and boys strongly believe we are superior to women and girls and that we can show it in the sexual act. There is no secret about it 'be a man' means to have sex. (Man, single-sex FGD, rural)

Women who spoke about the power differential with more apprehension and at times anger:

It is how women are thought to be. We do not have an equal say but that is the way it is. I am telling you, this is not a good thing and we see that in other places it is not this way. If you have a boy you are a good wife and you know that boy will be treated the best by the father. (Woman, single-sex FGD, rural)

\section{'But, a woman can kill a cat': Women as agents}

The powerlessness of women may be exaggerated when individuals speak about what it means to be a man. Thus, we looked for examples where women are not merely victims of oppression. Owambos have a saying that comes up when discussing women's weakness, 'But, a woman can kill a cat'. It assumes that women have their own ways of asserting power and can at times be more sly and powerful than a cat. Men told stories about women's power to rape men, although most women felt the stories were 'made up to even things out'. However, examples of women's agency did emerge in the data, and provide insight into the extent to which Owambo women can exert control over their sexual lives. For example, one young woman described the circumstances surrounding her decision to get an HIV test based on the fear that her boyfriend had other girlfriends and was HIV positive:

He said he would marry me. He said he had to have me. In the light of the day I know he is just speaking nonsense, but in the dark I just close my eyes and feel that what he says is true. I am making the decision to fool myself. (Woman, KI, rural) 
A woman in Ongwediva told the story of being involved in an HIV prevention programme for out-of-school youth. She met with groups of young people on a weekly basis knowing she was pregnant and HIV positive. She said:

This is what I am choosing now, to be strong and teach my peers about the tricks of men and this horrible disease. Before I listened to his sweet words but I have to make my choices now. (Woman, KI, urban)

These examples illustrate how women were able to make choices; however, these choices were based on a limited sense of agency in reaction to negative experiences with men. One rural man summed up the issue of power and gender as follows: "Men are more powerful from birth, more important. Today women are on the move, but it is not balanced."

\section{Education, tension and an answer}

Education is often held up as a potential solution to improving social conditions. Both male and female participants stressed education as the path to getting a job, 'To have an education in this country is very good. A job might or might not follow but you are putting yourself in the position' (Man, KI, urban).

Indeed, education and a job were seen as indicators of a strong man, in part because they allow access to material goods. As one woman said, 'Men now, in the cities have many girlfriends, and education, and a job. They may also have a traditional home in the North'. In this way, education was seen as associated with the 'urban lifestyle'. Perhaps because of this, focus groups and interviews with students at the teachers college were marked with tension about how education might affect ideas of masculinity. Teaching men to change behaviour was identified as an important step by all women and a minority of men. But, the role of education in achieving the goal was controversial, because formal education further consolidated what it was to be a man:

It is the educated men that have traditional wives in the village and many girlfriends in the town and believe it is their right to both that are the problem for HIV/AIDS in the country. (Woman, KI, urban)

Another woman stressed:

We should be the leaders. We made it to further education and men are not being role models. They are afraid of changing. (Woman, FGD, urban)

Respondents also spoke of the value of religious education. Two rural men offered ideas for change that were fuelled by religion. Religion was identified as a map to follow in tough times, and referred to as the 'only hope' for cultural change in the face of HIV. Religion was also spoken about as 'something for the women and children to do'. Women noted that the majority of the church is filled with women and children: 'The men are scarce on Sunday. I ask myself, "Where are they?"

\section{'It's only omuloudu': Masculinity and alcohol}

Prior research in sub-Saharan Africa has identified alcohol use as a crucial factor linked to the transmission of HIV (e.g., Mbulaiteye et al. 2000). The relationship between masculinity and alcohol was complex, perhaps because alcohol use has changed in recent times. 
Appropriate drinking in Owamboland reflects rules about both what to drink and who can drink. Traditional alcohol had both age and gender rules associated with its use; however, these norms appear to be changing, leading to the identification of alcohol as a major social problem.

In general, male key informants identified alcohol as a symbol of masculinity, stating 'if you are serious about your drink, you are a man'. In contrast, female informants reported more tenuous linkages between alcohol and masculinity, with most women reporting that a man who does not drink is highly valuable to women.

Women like men who do not drink at all or know the moderate way to use alcohol. If they only drink omuloudu (traditional millet beer) they are most probably ok. If they drink the Squadron [rum] one has big problems. He thinks he is a big man. (Woman, single-sex FGD, rural)

Several men reported only drinking traditional beer (omuloudu) and vehemently refuting 'Western drinks'. 'Oumuloudu makes you strong and Tafel (bottled beer) makes you weak'. Cucu shops (selling Western alcohol) were labelled as 'houses of no good' by some respondents, because men lose other things they value if they frequent them. In addition, alcohol was seen by both men and woman as unfettering traditional sexual regulations:

When a man drinks it is for many reasons. But this man's first and foremost reason soon turns to the ladies. If he sees a lady drinking it is known that she wants to have sex. She may not but he is already drunk so he assumes. (Man, FGD, rural)

\section{The alliance of masculinity and HIV}

A final theme was the joining together of masculinity and HIV/AIDS. Not many years ago, Namibians could be heard stating that AIDS did not exist, or 'I will believe AIDS is here when someone dies from it and I see it with my own eyes. Until then let's discuss other things' (man, KI, rural). This is no longer the case; none of the participants in this study expressed the idea that AIDS did not exist. People knew that AIDS is a virus and condoms are the best prevention. When asked why men and women were not using condoms, explanations focused on the need for 'flesh on flesh contact' and the 'waste of time' to use condoms. However, when asked more specific questions about what others thought of AIDS, several cultural myths emerged. Several informants expressed the following ideas: 'AIDS is a punishment from God', 'AIDS is caused by a curse or witchcraft', 'Sex with a child or virgin can cure men of AIDS'. Women described men as not wanting to die alone so they try to infect as many people as possible; one urban woman said, 'I have heard that some men will purposefully try to get you to die with them. They are afraid, I know, but they are cowards, too'.

In addition, several explanations of HIV encompassed notions of masculinity. The spread of HIV was also attributed to the military, alcohol use, and the prevalence of multiple partners due to culture and migrant labour; these are almost entirely male activities. The resilience of a notion of masculinity emphasizing virility and a denial of health concerns persists in current narratives regarding AIDS. In the words of one respondent, 'AIDS is different, but a long time ago, a man that did not have syphilis was not a man' (male, single-sex FGD, rural). Several key informants retold adages currently circulating in Owamboland regarding HIV, such as, 'AIDS didn't come to Africa for dogs, it came for 
men' (man, KI, urban). A rural women retold a saying she heard men using, 'If you do not die of AIDS you are not a man'. Not once did participants allude to femininity or include women in their understanding of HIV/AIDS. Explanations of HIV and AIDS thereby integrated the acquisition of the disease with the meaning of masculinity, extending what it means to be a man into the grave.

\section{Discussion}

Despite high rates of HIV/AIDS in Namibia, little published literature exists on local factors contributing to the epidemic. Thus, our goal in this study was to explore evolving masculinities, attitudes, and behaviours related to HIV/AIDS among speakers of Owambo, the largest language group in Namibia. Two over-arching questions were addressed. The first centred on the meanings of masculinity in contemporary Owambo society, and the second on potential linkages between notions of masculinity and HIV. Thematic analysis of open-ended responses from key informant interviews and focus group discussions provide initial answers to these questions, and highlight directions for future research and intervention efforts.

Cultural groups construct ideal notions of masculinity that represent models for behaviour, even if not all individuals adhere to them. When asked what it means to be a man, respondents showed widespread agreement on what constituted traditional and contemporary ideals of masculinity. Scholars have criticized the categorization of constructs into 'traditional' and 'modern' (e.g., Dilger 2003); however, because our participants characterized masculinity as having a 'traditional' and a 'contemporary' component, we chose to report this dichotomy and examine which aspects of masculinity show continuity with the past, and which have changed. In describing both traditional and contemporary notions of masculinity, participants identified having multiple sexual partners and fathering many children as critical attributes. Other indicators of masculinity were markers of material possessions. In the past, and currently in rural settings, agricultural wealth (e.g., cattle and a large millet field) was emphasized. However, modern markers of wealth have replaced or been added to those traditionally associated with masculinity, particularly in urban areas; now, one must also have a car, money, education, and a job. Similarly, in Zambia a girl's ideal boyfriend has been reported as someone who has the 'four C's' (car, crib, cash, and a cell-phone) (Price and Hawkins 2002). As Waetjen (2004) argues that a rural and urban masculinity exists, our findings allude to markers of masculinity that are more salient depending on place of residence.

These notions of masculinity can be linked to the HIV epidemic directly and indirectly. The most direct linkages emerged in the way HIV was characterized in everyday life. Luyt (2003) discussed the social representations of masculinity among South African men by examining metaphorical language. He described metaphor as a way to understand unfamiliar concepts in terms of existing explanatory systems. Similarly, the Owambo saying, 'AIDS didn't come to Africa for dogs, it came for men' may be a creative way for men to express their masculinity against the novel threat of HIV/AIDS and gain control over an otherwise uncontrollable disease by relating it to existing gender norms of male domination and power. In keeping with this notion, respondents described sexually transmitted infections as a marker of manhood (syphilis in the past, HIV in the present). Another linkage between HIV and masculinity stems from deeply held notions equating masculinity with sexual prowess and fatherhood, which may contribute directly to the HIV epidemic by encouraging individuals to engage in unprotected sex. These findings extend 
the argument that multiple sexual partners are a feature of masculinity in the midst of the AIDS epidemic as well as an important marker of manhood into the grave.

Some evidence of changing attitudes and behaviour did emerge from our research. For example, women expressed concern and anger at the risk posed by their partners, and examples were given of resistance by women. In addition, the potential role of education in stemming the epidemic was emphasized by some participants, although respondents espoused contradictory views about the value of education. Some blamed the spread of HIV on educated men, whose education leads to high-paying jobs and access to the material possessions that allow them to attract sexual partners. A recent qualitative study of secondary school students in Botswana revealed that boys and girls are aware of the disparities in the opportunities for girls in the education system as well as in life (Commeyras and Montsi 2000). Similar to the narratives of participants in this study, the authors conclude that education in Africa is both a place where gender equity is taught and a place where boys become more socialized to oppress women. Thus, despite inklings of change the equation of masculinity with sexual prowess appears to be persistent. Work in other African nations highlights the challenge such attitudes will likely pose to promoting behaviour change (e.g., Abdool-Karim et al. 1992, Campbell 1997).

Ideals of masculinity also define avenues for achieving manhood. Scholars have proposed that men exaggerate elements of their masculinity to gain approval when they do not naturally fit the cultural ideal (Thompson and Pleck 1986, Courtenay 2000). Thus, the extent to which men are able to meet contemporary notions of masculinities may have an indirect impact on the HIV epidemic. There is ample evidence that many men in Namibia do not have access to the material possessions they associate with 'being a man'. For example, according to the 2000 Demographic Health Survey (2000), Namibia reports unemployment rates as high as $68 \%$. Moreover, while $85 \%$ of children attend primary schools, in 1998 only $11 \%$ of Grade 12 students passed the standardized tests for graduation at Haimbili Haifiku Secondary School in Eenhana, with similar numbers found in more urban areas. Finally, car ownership rates are low: $77.8 \%$ of households in rural areas of Namibia do not own a car. These statistics indicate that meeting certain definitions of masculinity may be a daunting endeavour.

In light of these barriers, alternative masculinities may gain increased importance (Wood and Jewkes 2001). Our study indicates that in contemporary Namibia, sexual activity and alcohol use are important ways of attaining manhood. Having multiple partners and fathering many children were at the core of descriptions of what it means to be a man in Owambo society. Alcohol has been identified as an important factor in understanding HIV transmission in Africa (Mufune et al. 2000, Wojcicki 2002), and our findings support the notion that alcohol use and social problems resulting from alcohol are linked to changing notions of masculinities. In the absence of alternative pathways to masculinity, it would not be surprising if Owambo men increasingly turned to sexual activity and alcohol use as ways of expressing their manhood.

\section{Limitations, implications, and future directions}

A number of limitations should be kept in mind when interpreting the results of this exploratory study. While purposive sampling was used to select people who represented a variety of opinions, the full range of views and beliefs may not be reflected. In addition, data was collected by 'outsider' researchers with the aid of a Namibian translator, which might pose a problem if participants are unwilling to share information with unfamiliar research- 
ers. Although the first author had three years prior experience working and living in Northern Namibia, hiring local interviewers might be useful. Finally, focus groups may not be the best method to explore sensitive topics like gender and sexuality; individual interviews may provide additional insight in future research. Despite these caveats, the current study provides novel information about masculinity and HIV/AIDS within an under-studied population, and the findings can be used to guide future research and intervention efforts.

Programmatic implications. The findings from this study can also be used to make programme-related recommendations. Interventions that address alcohol abuse are needed, given the observed relations between contemporary forms of alcohol use, sexual disinhibition, and domestic problems. Schools also appear to offer potential opportunities for educating the country's future leaders but a need exists to understand the nuances of education as it relates to gender relations. Another approach would be to build on Morrell (2001), who groups men's responses to change in South Africa into three categories: reactive, accommodating and progressive. Many of the voices heard in our study were of a reactive nature: in an effort to reassert power, men are trying to reverse change. Men exhibiting accommodating and progressive responses may serve as role models for change in intervention efforts. Given that masculinity in Namibia is so strongly equated with multiple sexual partnerships and fatherhood (behaviours that directly contradict typical risk reduction messages), successful HIV prevention efforts will likely involve fostering changes in notions of masculinity and providing alternative avenues for attaining manhood. More specifically, the involvement of male peers into HIV prevention programmes would be helpful. Programmes might, for example, identify and train those men who endorse and display progressive responses to the crisis and who also possess the markers of socially desired masculinity. Programmes may emphasize the other aspects of masculinity, like education, and entrepreneurship, while de-emphasizing sexual prowess. To fully achieve these ends, however, broad-based efforts that directly address economic, structural, and cultural barriers to change will be needed.

\section{Acknowledgements}

This research was supported by a grant to J. Sorrell from the College of Medicine, University of Nebraska Medical Center. Research assistance was provided by Peter Hangula and Cecelia Nakamwe in Namibia, and Lisa Darveau and Jason McClaren in the USA. Manuscript preparation was partially supported by a Faculty Development Fellowship to M. Raffaelli from the College of Arts and Sciences, University of Nebraska-Lincoln.

\section{References}

Abdool-Karim, S., Abdool Karim, Q., Preston-Whyte, E. and Sanka, N. (1992) Reasons for lack of condom use among high school students. South African Medical Journal, 82, 107-110.

Bolton, R. (1995) Rethinking anthropology: The study of AIDS. In H. ten Brummelhuis and G. Herdt (eds.) Culture and Sexual Risk: Anthropological Perspectives on AIDS (Sydney: Gordon \& Breech), pp. 285-313.

Bujra, J. (2002) Targeting men for a change: AIDS discourse and activism in Africa. In F. Cleaver (ed.) Masculinities Matter (London: Zed Books), pp. 209-234.

Campbell, C. (1997) Migrancy, masculine identities and AIDS: The psychosocial context of HIV transmission on the South African gold mines. Social Science and Medicine, 45, 273-281. 
Campbell, C. and Williams, B. (1996) Academic research and HIV/AIDS in South Africa. South African Medical Journal, 86, 55-60.

Commeyras, M. and Montsi, M. (2000) What if I woke up as the other sex? Batswana youth perspective on gender. Gender and Education, 12, 327-346.

Connell, R. W. (1987) Gender and Power: Society, the Person and Sexual Politics (Stanford, CA: Stanford University Press).

Courtenay, W. (2000) Constructions of masculinity and their influence on men's well being: a theory of gender and health. Social Science and Medicine, 50, 1385-1401.

Creswell, J. W. (2003) Research design: Qualitative, Quantitative, and Mixed Method Approaches. second edition (Thousand Oaks, CA: Sage).

Demographic Health Survey, (2000) Namibia Final Report. Available at: http://www.measuredhs.com/pubs/pdftoc.cfm?ID5440\&PgName5country.cfm0ctry_id528

Dilger, H. (2003) Sexuality, AIDS, and the lure of modernity: Reflexivity and morality among young people in rural Tanzania. Medical Anthropology, 22, 23-52.

Fitzgerald, A., Stanton, B., Terreri, N., Shipena, H., Li, X., Kahihuata, J., Ricardo, I., Galbraith, J. and De Jaeger, A. (1999) Use of western-based HIV risk reduction interventions targeting adolescents in an African setting. Journal of Adolescent Health, 25, 52-61.

Foreman, M. (1999) AIDS and Men (London: Panos/Zed Books).

Gilmore, D. (1990) Manhood in the Making: Cultural Concepts of Masculinity (New Haven, CT: Yale University Press).

Heise, L. and Elias, C. (1995) Transforming AIDS prevention to meet women's needs: A focus on developing countries. Social Science and Medicine, 40, 941-943.

LeBeau, D., Fox, T., Becker, H. and Mufune, P. (1999) Taking Risks, Taking Responsibility: An Anthropological Assessment of Health Risk Behaviour in Northern Namibia (Windhoek: University of Namibia).

Luyt, R. (2003) Rhetorical representations of masculinities in South Africa: Moving towards a material-discursive understanding of men. Journal of Community and Applied Social Psychology, 13, 26-69.

MacPhail, C. and Campbell, C. (2001) 'I think condoms are good but, aai, I hate those things': Condom use among adolescents and young people in a Southern African township. Social Science and Medicine, 52, 1613-1627.

Mbulaiteye, S. M., Ruberantwari, A., Nakiyingi, J. S., Carpenter, L. M., Kamali, A. and Whitworth, J. A. (2000) Alcohol and HIV: a study among sexually active adults in rural southwest Uganda. International Journal of Epidemiology, 29, 911-915.

McCreary, D., Wong, F., Wiener, W., Carpenter, K., Engle, A. and Nelsom, P. (1996) The relationship of masculine gender role stress to psychological adjustment. A question of construct validity. Sex Roles, 34, 507-516.

Morrell, R. (2001) The times of change: Men and masculinity in South Africa. In R. Morrell (ed.) Changing Men is Southern Africa (Pietermartizburg: University of Natal Press), pp. 3-37.

Mufune, P. (2003) Changing patterns of sexuality in northern Namibia: Implications for the transmission of HIV/ AIDS. Culture, Health and Sexuality, 5, 425-438.

Mufune, P., Fox, T. and LeBeau, D. (2000) Poverty, alcohol, migrancy and AIDS: social factors that facilitate HIV/AIDS transmission in rural northern Namibia, Presented at The XIII International AIDS Conference 2000. Abstract no. WePeD4613.

Myer, M., Mathews, C. and Little, F. (2002) Condom use and sexual behavior among individuals procuring free male condoms in South Africa: A prospective study. Sexually Transmitted Diseases, 29, 239-241. 
Parker, R., Easton, D. and Klein, C. (2000) Structural barriers and facilitators in HIV prevention: A review of international research. AIDS, 14, S22-S32.

Parry, C. D., Bhana, A., Myers, B., Pluddemann, A., Flisher, A. J., Peden, M. M. and Morojele, N. K. (2002) Alcohol use in South Africa: Findings from the South African community epidemiology network on drug use (SACENDU) project. Journal of Studies on Alcohol, 63, 430-435.

Pattman, R. (2001) 'The beer drinkers say I had a nice prostitute, but the church goers talk about things spiritual': Learning to be men at a teachers' college in Zimbabawe. In R. Morrell (ed.) Changing Men in Southern Africa (Pietermartizburg: University of Natal Press), pp. 225-238.

Price, N. and Hawkins, K. (2002) Researching sexual and reproductive behaviour: A peer ethnographic approach. Social Science and Medicine, 55, 1325-1336.

Raffaelli, M. and Pranke, J. (1995) Women and AIDS in developing countries. In A. O'Leary and L. Jemmott (eds.) Women at Risk: Issues in the Primary Prevention of AIDS (New York: Plenum), pp. 219-236.

Schoeff, B. (1995) Culture, sex research, and AIDS prevention in Africa. In H. ten Brummelhuis and G. Herdt (eds.) Culture and sexual risk: Anthroplogical pespectives on AIDS (Sydney: Gordon \& Breech), pp. 29-51.

Seal, D. W. and Ehrhardt, A. A. (2003) Masculinity and urban men: perceived scripts for courtship, romantic, and sexual interactions with women. Culture, Health and Sexuality, 5, 295-319.

Thompson, E. and Pleck, J. (1986) The structure of male role norms. American Behavioral Scientist, 29, 531-543.

UNAIDS (2003) Report on the global HIV/AIDS epidemic 2002, UNAIDS. Available at: http://www.unaids.org/epidemic update/report

Waetjen, T. (2004) Workers and Warriors: Masculinity and the Struggle for Nation in South Africa (Chicago, IL: University of Illinois Press).

Wojcicki, J. (2002) 'She drank his money': Survival sex and the problem of violence in taverns in Gauteng province, South Africa. Medical Anthropology Quarterly, 16, 267-293.

Wood, K. and Jewkes, R. (2001) “Dangerous' love: reflections on violence among Xhosa township youth. In R. Morrell (ed.) Changing Men in Southern Africa (Pietermartizburg: University of Natal Press), pp. 317-336. 